Research Paper

\title{
Concomitant production of detergent compatible enzymes by Bacillus flexus XJU-1
}

\author{
Francois N. Niyonzima, Sunil S. More \\ Department of Biochemistry, Center for Post Graduate Studies, Jain University, Bangalore, India.
}

Submitted: May 10, 2013; Approved: December 13, 2013.

\begin{abstract}
A soil screened Bacillus flexus XJU-1 was induced to simultaneously produce alkaline amylase, alkaline lipase and alkaline protease at their optimum levels on a common medium under submerged fermentation. The basal cultivation medium consisted of $0.5 \%$ casein, $0.5 \%$ starch and $0.5 \%$ cottonseedoil as an inducer forprotease, amylase, and lipase, respectively. The casein also served as nitrogen source for all 3 enzymes. The starch was also found to act as carbon source additive for both lipase and protease. Maximum enzyme production occurred on fermentation medium with $1.5 \%$ casein, $1.5 \%$ soluble starch, $2 \%$ cottonseed oil, $2 \%$ inoculum size, initial $\mathrm{pH}$ of 11.0 , incubation temperature of $37{ }^{\circ} \mathrm{C}$ and $1 \%$ soybean meal as a nitrogen source supplement. The analysis of time course study showed that $24 \mathrm{~h}$ was optimum incubation time for amylase whereas $48 \mathrm{~h}$ was the best time for both lipase and protease. After optimization, a 3.36-, 18.64-, and 27.33-fold increase in protease, amylase and lipase, respectively was recorded. The lipase was produced in higher amounts $(37.72$ $\mathrm{U} / \mathrm{mL}$ ) than amylase and protease about 1.27 and 5.85 times, respectively. As the 3 enzymes are used in detergent formulations, the bacterium can be commercially exploited to secrete the alkaline enzymes for use in detergent industry. This is the first report for concomitant production of 3 alkaline enzymes by a bacterium.
\end{abstract}

Key words: Bacillus flexus, alkaline enzyme, concomitant production, optimization.

\section{Introduction}

The amylase (E.C 3.2.1.1), lipase (EC 3.1.1.3) and protease (EC 3.4.21-24 and 99) are hydrolase enzymes that cleave the glycosidic, ester, and peptide bonds, respectively via the addition of water. The hydrolases account more than $75 \%$ of all industrial enzymes. Lipases, amylases and proteases represent for about 3,18 and $60 \%$, respectively of total worldwide sale of enzymes (Rao et al., 1998; Sharma et $a l ., 2001)$. The enzymes are mainly added to the detergents to improve the cleaning ability of detergents. When used in detergents, the proteases acted as protein stain removals, amylases remove starch-based food stains whereas lipases remove fatty stains (Gormsen et al., 1991). Crude alkaline lipase and alkaline protease from Bacillus licheniformis and Geobacillus were able to remove fat and protein stains on clothes in the presence and absence of commercial powder detergent (Amara et al., 2009). A mixture of lipase and protease coproduced from Serratia marcescens was also able to remove the blood and grease stains when added to the detergent (Mukesh kumar et al., 2012a).

Amylases, lipases and proteases can be produced from plants, animals and microorganisms. However, they are produced from microorganisms because of reduction of time, labor and cost (Mukesh kumar et al., 2012b; Mukhtar and Haq, 2012). Bacteria especially Bacillus species are well known to secrete extracellular enzymes such as amylases, proteases and lipases of potential commercial values (Mukesh kumar et al., 2012b; Mukhtar and Haq, 2012; Sangeetha et al., 2008; Shivakumar, 2012). This is possible because the generation time is shorter, the genetic material can be manipulated easily and the cultural conditions can be optimized easily (Gupta et al., 2004).

The production of enzymes by microorganisms as well as the enzyme yield depends on the nutritional factors especially carbon and nitrogen sources and physicochemical parameters such as initial $\mathrm{pH}$, incubation temperature and incubation time (Mukesh kumar et al., 2012a, 2012b). 
All these factors must be optimized for maximal enzyme production. The optimization avoids the use of enzyme substrates in excess, and this reduces the cost of the fermentation process (Hasan and Hameed, 2001; Sangeetha et al., 2008; Anwar et al., 2011). In multienzyme production system, the additives to the basal medium must be chosen with great care since they must allow the production of all enzymes at their optimum levels in a single cultivation. Protease and alpha amylase enzymes are produced under submerged and solid-state fermentations by bacteria, however appreciable amounts of enzymes were recorded with submerged fermentation (Mukhtar and Haq, 2012).

The production of enzymes with better properties is a continuous exercise. Since the production of detergent compatible enzymes using different fermentation processes is quite expensive (Sharma et al., 2001), the concomitant production of industrial enzymes in a single fermentation medium is a new challenge. The production of alkaline amylase, alkaline lipase and alkaline protease by Bacillus species using separate fermentation media have been extensively reported. Few reports are also available for Bacillus species concomitantly producing amylase and lipase (Anwar et al., 2011), amylase and protease (Mukesh kumar et al., 2012b; Mukhtar and Haq, 2012; Shivakumar, 2012) and lipase and protease (Sangeetha et al., 2008, 2010; Valasange and Bagewadi, 2012). But there are no reports for the concomitant production of all 3 enzymes of Bacillus species in a single fermentation medium. Bacillus flexus XJU-1 was recently shown to be an alkaline lipase producer. In the present study, the bacterium was induced to concomitantly produce 3 alkaline enzymes in a single production medium and the nutritional and physicochemical parameters were optimized for maximal enzyme production under submerged fermentation.

\section{Materials and Methods}

\section{Chemicals and reagents}

p-nitrophenylpalmitate (pNPP, CAS No. 1492-30-4) was procured from Sigma-Aldrich, Co, St Louis, MO (USA). Rhodamine B (CAS No. 81-88-9) and gum acacia (CAS No.9000-01-5) were purchased from HiMedia Laboratories (Mumbai, India). The other chemicals and reagents were brought from Merck Specialities Private Limited (Mumbai, India), Sd fine-Chem limited (Mumbai, India) and Qualigens fine chemicals (Mumbai, India).

\section{Bacterial strain}

The bacterial strain used in the present study was recently screened from the Bangalore potato field using serial dilution and spread plate techniques and identified as Bacillus flexus XJU-1 based on morphological, cultural, biochemical characteristics and 16S rDNA sequencing (Niyonzima and More, 2013b).

\section{Detection of amylolytic, lipolytic and proteolytic activities on agar plates}

The medium proposed by Kumar et al. (2012) was used for detecting enzymes with minor modification. It consisted of $0.5 \%(\mathrm{w} / \mathrm{v})$ casein, $2 \%(\mathrm{v} / \mathrm{v})$ olive oil, $0.2 \%$ (w/v) $\mathrm{NH}_{4} \mathrm{NO}_{3}, 0.2 \%$ (w/v) $\mathrm{MgSO}_{4}, 0.006 \%$ (w/v) $\mathrm{CuSO}_{4}$, $0.001 \%(\mathrm{w} / \mathrm{v})$ Rhodamine B and $1.5 \%(\mathrm{w} / \mathrm{v})$ agar. It was adjusted to $\mathrm{pH} 10.0$ with $2 \mathrm{M}$ sodium carbonate. The plates were inoculated with a $B$. flexus XJU-1 culture and incubated at $37{ }^{\circ} \mathrm{C}$ for $48 \mathrm{~h}$. The protease production was indicated by a clear zone of casein hydrolysis around the bacterial colony while the lipase was shown by the formation of orange halos around the organism upon irradiation with UV transilluminator (Model MD-25, Wealtec, India) at $350 \mathrm{~nm}$. The casein was replaced by $0.5 \%(\mathrm{w} / \mathrm{v})$ soluble starch in the above medium and the bacterium was grown in the same conditions. The formation of clear zone of starch hydrolysis after addition of iodine solution was an indication of the presence of amylase.

\section{Inoculum preparation, submerged fermentation and crude enzyme preparation}

Nutrient agar slants were streaked with $B$. flexus XJU-1 culture and incubated for $48 \mathrm{~h}$. One loop of the culture from the agar slant was taken and used to inoculate $25 \mathrm{~mL}$ of nutrient broth contained in $50-\mathrm{mL}$ conical flask. The incubation was carried out in an orbital incubator (Model S150, Stuart, India) at $100 \mathrm{rpm}$ for $24 \mathrm{~h}$ at $37^{\circ} \mathrm{C}$. The resulted inoculum was adjusted to $10^{7}$ colony forming units $/ \mathrm{mL}$ with nutrient broth prepared and sterilized in the same conditions. The standardized inoculum was used to carry out submerged fermentation.

Submerged fermentation was carried out in $250-\mathrm{mL}$ Erlenmeyer flask containing $100 \mathrm{~mL}$ of the medium consisted of $0.5 \%(\mathrm{w} / \mathrm{v})$ casein, $0.5 \%(\mathrm{w} / \mathrm{v})$ starch, $0.5 \%(\mathrm{v} / \mathrm{v})$ cottonseed oil, $0.2 \%(\mathrm{w} / \mathrm{v}) \mathrm{NaCl}$ and $0.01 \%(\mathrm{w} / \mathrm{v})$ $\mathrm{CaCl}_{2}, \mathrm{pH}$ 10.0. The medium was inoculated with $1 \%$ inoculum and the incubation was carried out in an orbital incubator (Model SI50, Stuart, India) at agitation speed of $100 \mathrm{rpm}$ for $48 \mathrm{~h}$ at $37^{\circ} \mathrm{C}$. After the incubation period, the bacterial cells were removed by centrifugation (Model C-30 BL, Cooling centrifuge, Remi, India) at 10,000 rpm for 10 min at $4{ }^{\circ} \mathrm{C}$. The clear supernatant was used as a crude enzyme source.

\section{Enzyme assays}

\section{Determination of alkaline amylase activity}

Amylase activity of the culture supernatant was estimated as per the modified method of Bernfeld (1955) using soluble starch as substrate. $0.5 \mathrm{~mL}$ of $0.2 \mathrm{M}$ Tris- $\mathrm{HCl}$ buffer $(\mathrm{pH} 8.5), 1 \%(\mathrm{w} / \mathrm{v}) \mathrm{mL}$ of soluble starch and $0.5 \mathrm{~mL}$ of crude enzyme were mixed together, and incubated for $10 \mathrm{~min}$ at $37^{\circ} \mathrm{C}$. After incubation period, $2 \mathrm{~mL}$ of DNS reagent was added and shaken well to arrest the reaction. The 
contents of test tubes were then incubated in a water bath for $15 \mathrm{~min}$. After incubation, the test tubes were allowed to cool down and $7 \mathrm{~mL}$ of distilled water was added into each test tube. The absorbance was recorded at $540 \mathrm{~nm}$ with a UV spectrophotometer (Model SL-159, Elico, India). The blank samples were without crude enzymes. One unit of alkaline amylase was defined as the amount of enzyme required to release $1 \mu \mathrm{mol}$ of glucose as reducing sugar per min per $\mathrm{ml}$ under the assay conditions.

\section{Determination of alkaline lipase activity}

The alkaline lipase activity of the crude enzymes was determined spectrophotometerically by the method reported by Sumathi and Meerabai (2012) with slight modification using pNPP in the emulsion. $1 \mathrm{mg}$ of pNPP was dissolved in $1 \mathrm{~mL}$ of 2-propanol (solution A) with a cyclomixer (Model CM 101, Remi, India) for $5 \mathrm{~min}$ at room temperature. $0.01 \mathrm{~g}$ of gum acacia and $0.04 \mathrm{~mL}$ of Triton $\mathrm{X}-100$ were dissolved in $9 \mathrm{~mL}$ of $50 \mathrm{mM}$ Tris $\mathrm{HCl}$ buffer $(\mathrm{pH} 8.5)$ (solution B) with a magnetic stirrer (Model 2MLH, Remi, India). The solution A was added one drop at a time to the solution B with vigorous stirring using a magnetic stirrer. The resulted emulsion served as a substrate solution. $0.9 \mathrm{~mL}$ of the substrate solution was mixed with $0.1 \mathrm{~mL}$ of crude enzyme, shaken well and incubated at $37{ }^{\circ} \mathrm{C}$ for 20 $\min$. The reaction was arrested by incubating in boiling water at $95{ }^{\circ} \mathrm{C}$ for $5 \mathrm{~min} .3 \mathrm{~mL}$ of $50 \mathrm{mM}$ Tris $\mathrm{HCl}$ buffer $(\mathrm{pH}$ 8.5 ) was added and mixed well. The enzyme solution was omitted in the control tube and was replaced with the same amount of buffer. The produced p-nitrophenol was measured using a UV-VIS spectrophotometer (Model SL-159, Elico, India) at $410 \mathrm{~nm}$. The unknown concentration of p-nitrophenol produced was deduced from a p-nitrophenol standard curve constructed in the $1 \mathrm{mg}$ to $5 \mathrm{mg}$ range. One unit $(\mathrm{U})$ of lipolytic activity was defined as the amount of enzyme required to produce $1 \mu \mathrm{mol}$ of $\mathrm{p}$-nitrophenol from pNPP per min per $\mathrm{ml}$ under the assay conditions.

\section{Determination of alkaline protease activity}

The alkaline protease activity was assayed as per Niyonzima and More (2013a) method. The amount of amino acids released was deduced from a standard curve constructed from known concentrations of tyrosine. One unit of alkaline protease was defined as the amount of enzyme required to release $1 \mu \mathrm{mol}$ of tyrosine per min per $\mathrm{ml}$ under the assay conditions.

\section{Optimization of nutritional and physicochemical factors}

The carbon and nitrogen sources as nutritional factors and inoculum level, initial $\mathrm{pH}$ and incubation temperature as physicochemical factors were optimized in this study. The time course of maximal enzyme production was also studied. The strategy used was to optimize one factor each time keeping all other factors unchanged and use the opti- mized condition in the subsequent experiments. The influence of casein and starch concentrations in the range $0.5 \%$ to $3 \%(\mathrm{w} / \mathrm{v})$ on the enzyme secretion by the bacterium was studied. The effect of cottonseed oil concentration was also analyzed in the range 0.5 to $3.5 \%(\mathrm{v} / \mathrm{v})$. The cultivation media were inoculated with different inoculum levels (from 1 to $5 \%, \mathrm{v} / \mathrm{v}$ ). The $\mathrm{pH}$ of the cultivation medium was adjusted from 7.0 to 13.0 to investigate the effect of initial $\mathrm{pH}$ on enzyme production. Four temperatures viz. 30, 37, 45 and $55{ }^{\circ} \mathrm{C}$ were used to study the effect of incubation temperature on the production of alkaline enzymes. The effect of nitrogen source $(0.5 \%, \mathrm{w} / \mathrm{v})$ as additive to the cultivation medium was studied. The effect of best nitrogen source concentration (soybean meal) was also analyzed in the 0.5 to $3 \%(\mathrm{w} / \mathrm{v})$ range. The submerged fermentation, crude enzyme preparation and enzyme activity determination were carried out as described earlier.

\section{The time course of alkaline enzyme production}

After optimization of various nutritional and physicochemical parameters, time course was analyzed in order to know the optimum time for enzyme production. The medium of $\mathrm{pH} 11.0$ composed of $1.5 \%$ casein, $1.5 \%$ starch, $2 \%$ cottonseed oil, $0.2 \%(\mathrm{w} / \mathrm{v}) \mathrm{NaCl}, 0.01(\mathrm{w} / \mathrm{v}) \mathrm{CaCl}_{2}$ and $1 \%$ soybean meal was inoculated with $2 \%$ inoculum. The culture flasks were incubated in an orbital shaker incubator with $100 \mathrm{rpm}$ as agitation speed at $37^{\circ} \mathrm{C}$. The activity was recorded at regular intervals after exactly $12 \mathrm{~h}$ for a period of $72 \mathrm{~h}$.

\section{Statistical analysis}

All the experiments were carried out independently with each treatment replicated three times. The significant differences among the means for each parameter were given by one way analysis of variance (ANOVA) followed by Duncan's multiple range test (DMRT) at the 5\% significance level with the help of SPSS software.

\section{Results and Discussion}

A bacterium used in this work was screened from the potato field soil of Bangalore (India). It was identified as $B$. flexus XJU-1 based on cultural, microscopic, biochemical and molecular techniques (Niyonzima and More, 2013b). The strain was able to secrete alkaline lipase with cottonseed oil as the best lipidic carbon source (data not shown). In the present study, the bacterium was also induced to secrete alkaline protease and alkaline amylase by cultivating it on a basal medium consisting of casein, starch and cottonseed oil. The casein and starch acted as a carbon source for protease and amylase production, respectively. In addition, the casein served as nitrogen source for the production of all enzymes. 


\section{Production of alkaline enzymes on agar plates}

When the casein olive oil Rhodamine agar plates were streaked with $B$. flexus XJU-1 culture, a clear zone of casein hydrolysis around the bacterial colony was seen and indicates the proteolytic activity. An orange halo around the organism was also observed upon irradiation with UV transilluminator at $350 \mathrm{~nm}$ and indicates lipolytic activity (Figure 1A). When starch olive oil Rhodamine agar plates were streaked with $B$. flexus XJU-1 colonies, an amylolytic activity was shown by a clear zone of starch hydrolysis around the organism. The zone was clearly seen after iodine solution addition (Figure 1B). The bacterium is thus producing 3 alkaline enzymes. Similarly, amylolytic and proteolytic activities were also seen when Bacillus species were streaked on starch casein agar plates (Mukesh kumar et al., 2012b; Shivakumar, 2012). The formation of orange fluorescent halo zones around the Bacillus species was a condition used by Niyonzima and More (2013) to screen for true lipase producers. The fluorescent zones are seen due to the formation of fluorescent compounds resulted from the complexation reaction between Rhodamine B dimers and fatty acids, monoglycerides and diglycerides released from oil in the growth medium (Hou and Johnston, 1992).

\section{Optimization of nutritional and physicochemical factors}

\section{Effect of varying casein concentration on the production of alkaline enzymes}

In the living systems including bacteria, carbon sources have two important roles. They provide raw material for the structure and act as an energy source (Hasan and Hameed, 2001). When different amounts of casein were added to the basal medium, the maximum activity of all alkaline enzymes was observed at $1.5 \%$ although statistically at par with $2 \%$ (Figure 2). The $1.5 \%$ casein concentration was used in the optimization of next parameter as it is more economical. A gradual decrease in enzyme activities was seen with higher casein levels (Figure 2). Casein served as a specific inducer at appropriate concentration, whereas at higher concentration, it acted as substrate repressor. In yeast cells, the decrease in enzyme production at higher casein concentrations was ascribed to substrate repression (Ogrydziak, 1993). In addition to serve as a carbon source for protease production, casein acted as a nitrogen source for the production of all the 3 enzymes. Supportively, in the concomitant production of lipase and protease by Bacillus pumilus SG2, casein was a better nitrogen source than others tested, namely gelatin, yeast extract and beef extract (Sangeetha et al., 2008).

\section{Effect of varying starch concentration on the production of alkaline enzymes}

The influence of different concentrations of soluble starch was analyzed. An 8.25-fold increase in amylolytic

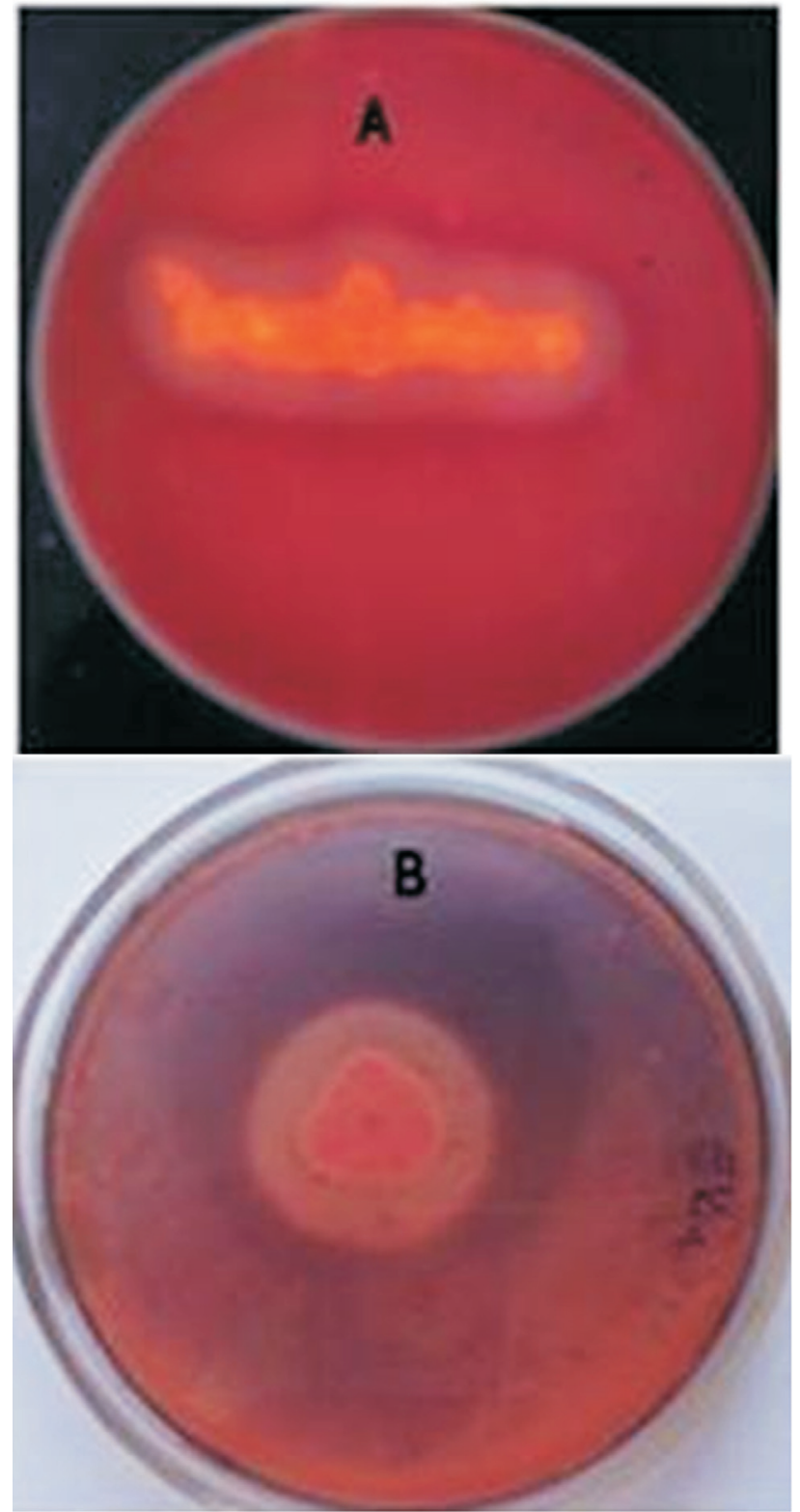

Figure 1 - Bacillus flexus grown on casein cottonseed oil Rhodamine B agar plate (A) and on starch cottonseed oil Rhodamine B agar plate (B).

activity was obtained with $1.5 \%$ soluble starch. The protease and lipase activities were also optimum at this concentration with 1.57- and 10.96-fold increase, respectively (Figure 3 ). This is evident for alkaline amylase because soluble starch acted as its inducer. However, for alkaline protease and lipase, the starch may be acting as a carbon source additive for enzyme production. Similarly, the soluble starch was among the chief ingredients in the fermentation medium for protease (and amylase) production by Bacillus subtilis IIB-26 (Mukhtar and Haq, 2012). Likewise, soluble starch was the best carbon source supplement for lipase production by Bacillus subtilis JPBW-9 (Anwar et al., 2011). Furthermore, $1 \%$ casein and $1 \%$ 


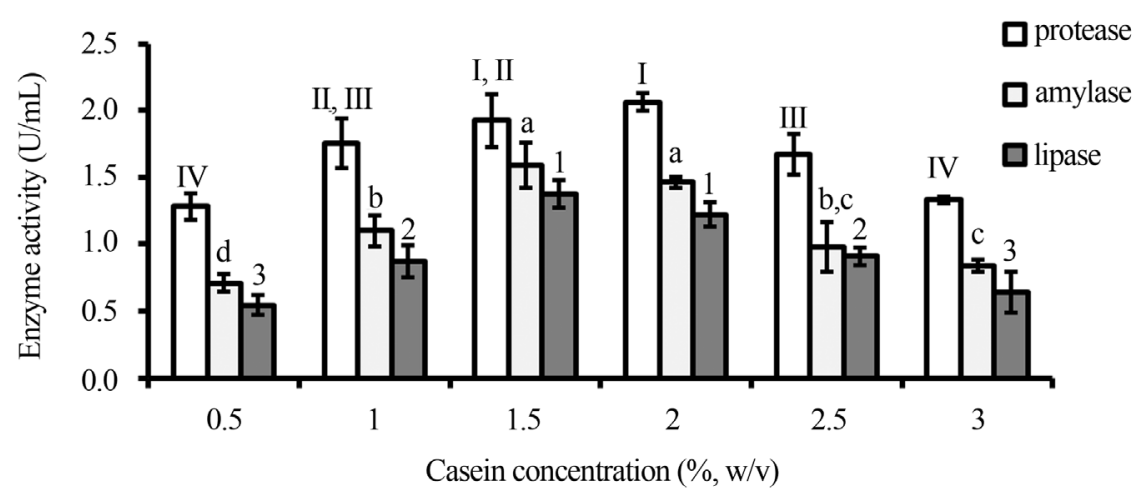

Figure 2 - Effect of different casein concentrations on the production of alkaline enzymes by Bacillus flexus XJU-1. 0.5\% casein was control. The significant difference at $\mathrm{P}_{0.05}$ is indicated by different letters or numerals or Roman numerals on the error bars.

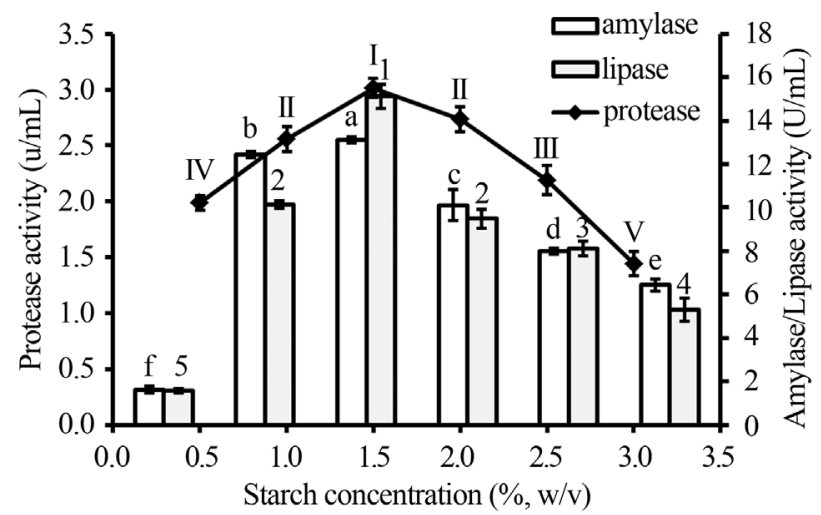

Figure 3 - Effect of different starch concentrations on the production of alkaline enzymes by Bacillus flexus XJU-1. 0.5\% starch was control. The significant difference at $\mathrm{P}_{0.05}$ is indicated by different letters or numerals or Roman numerals on the error bars.

starch in a single cultivation medium enhanced protease (3.73 fold) and amylase (2.07 fold) production in Aspergillus awamori (Negi and Banerjee, 2010). In Serratia rubidaea, starch was an appropriate substrate for maximal lipase production (Immanuel et al., 2008).

\section{Effect of varying cottonseed oil concentration on the production of enzymes}

Lipidic carbon sources especially natural oils were experimentally reported by many researchers to be essential for obtaining a high lipase yield as acted as inducers (Bora and Bora, 2012). The ability of the isolate to grow in different concentrations of cottonseed oil was tested. The amylase and protease showed important activities in 0.5 to $2 \%$ cottonseed oil. However, the maximum activities for all 3 enzymes were obtained at $2 \%$ cottonseed oil concentration, after which a decrease in activities was observed (Figure 4). This decrease in enzyme activity may be ascribed to the accumulation of higher oil concentrations preventing proper bacterial culture aeration, affecting bacterial growth and thus enzyme production. Similarly, a delay in mycelial growth was seen due to poor aeration resulting in little enzyme yield (Maia et al., 1999).

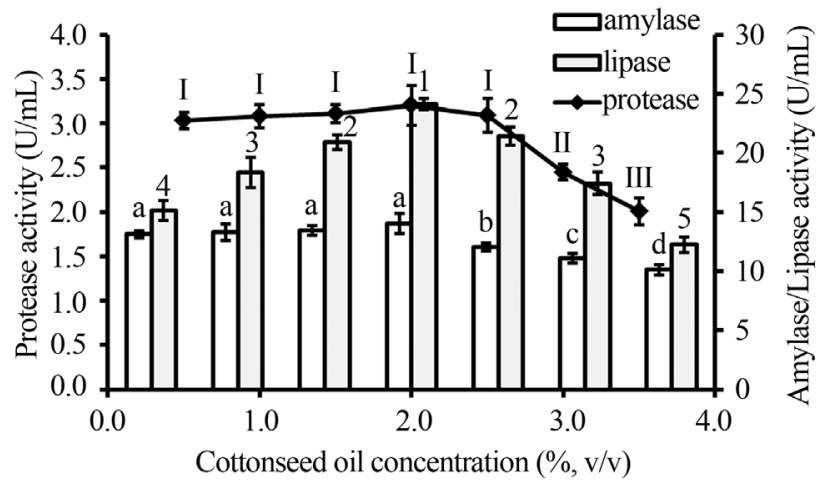

Figure 4 - Effect of different concentrations of cottonseed oil in the production of alkaline enzymes by Bacillus flexus XJU-1. 0.5\% cottonseed oil was a control. The significant difference at $\mathrm{P}_{0.05}$ is indicated by different letters or numerals or Roman numerals on the error bars.

\section{Effect of inoculum size on the production of alkaline enzymes}

The inoculum size is one of the important factors for bacterial growth and enzyme production, especially under submerged fermentation. Different inoculum concentrations in the 1 to $5 \%$ range were investigated for the production of alkaline enzymes by B. flexus XJU-1. Maximum yield for all 3 enzymes were observed at $2 \%$ inoculum size after which the activities gradually decreased (data not shown). 1\% inoculum also gave a significant amylase yield. The gradual decline in enzyme activities observed with higher inoculum levels may be probably attributed to the insufficiency of some nutrients owing to fast bacterial growth. A higher inoculum size of $10 \%$ was the best for lipase and $\alpha$-amylase production in B. subtilis JPBW-9 (Anwar et al., 2011). Therefore, the effect of inoculum size on enzyme production may depend on the bacterial efficiency, stability, type and size.

\section{Effect of initial pH on the production of alkaline enzymes}

The initial $\mathrm{pH}$ plays a crucial role in bacterial growth and thus in enzyme production. If the bacteria are screened and isolated at alkaline $\mathrm{pH}$, the enzymes produced may 
have higher activities in the alkaline region (Hasan and Hameed, 2001). After investigating the effect of the initial $\mathrm{pH}$ of the fermentation media, the enzyme productions appeared to occur at a range of optimum $\mathrm{pH}$ viz. 10.0, 11.0 and 12.0. The maximum yield for all the enzymes however was at $\mathrm{pH}$ 11.0, beyond which the activities declined (Figure 5). This clearly shows the alkalophilic nature of this strain. Similarly, the optimum $\mathrm{pH}$ was the same for amylase and protease (Shivakumar, 2012) or lipase and protease (Amara et al., 2009; Sangeetha et al., 2010; Valasange and Bagewadi, 2012) secreted by Bacillus species. The similarity in $\mathrm{pH}$ optima of enzymes produced by Bacillus species has been ascribed to genetic similarity in enzyme sequences (Anwar et al., 2011). The concomitant production of amylase and lipase, amylase and protease or lipase and protease at optimum level of different Bacillus species in the alkaline region from 7.5 to 10.0 has been reported (Sangeetha et al., 2008, 2010; Anwar et al., 2011; Mukesh kumar et al., 2012b; Mukhtar and Haq, 2012; Shivakumar, 2012; Valasange and Bagewadi, 2012). A decrease in enzyme activities was noted after optimum $\mathrm{pH}$. This decline has been ascribed to the alteration of transport mechanisms across the microbial membrane that may prevent release of enzymes (Hasan and Hameed, 2001).

\section{Effect of incubation temperature on the production of alkaline enzymes}

The physical factors like incubation temperature, initial $\mathrm{pH}$ and aeration play a vital role in enzyme production as they modulate bacterial growth (Gupta et al., 2004). Enzyme production was observed in all the temperatures tested with optimum for all enzymes at $37^{\circ} \mathrm{C}$ although statistically at par with 30 and $45^{\circ} \mathrm{C}$ (data not shown). This shows the mesophilic nature of the Bacillus flexus XJU-1. The incubation temperature of $37^{\circ} \mathrm{C}$ was also good for the coproduction of amylase and protease (Mukhtar and Haq, 2012; Shivakumar, 2012), and lipase and protease (Sangeetha et al., 2008; Valasange and Bagewadi, 2012) by

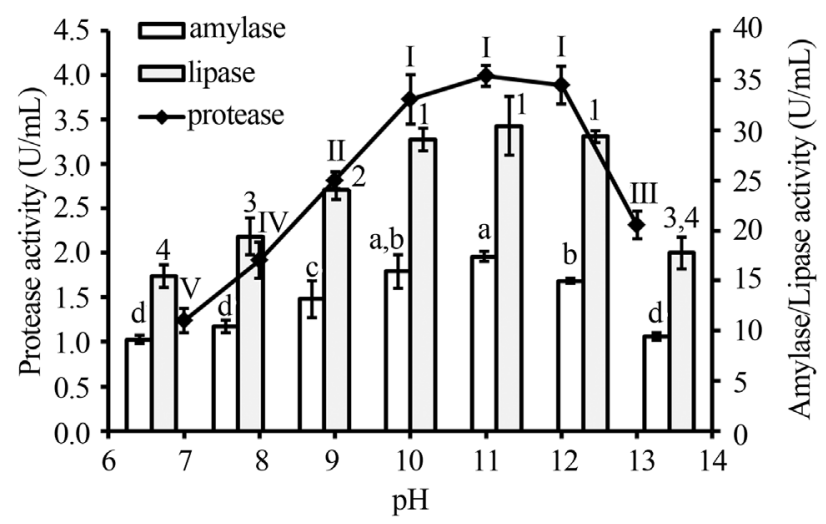

Figure 5 - Effect of different initial pHs on the production of alkaline enzymes by Bacillus flexus XJU-1 under submerged fermentation. The $\mathrm{pH}$ 10.0 was a control. The significant difference at $\mathrm{P}_{0.05}$ is indicated by different letters or numerals or Roman numerals on the error bars.
Bacillus species. The production of all enzymes decreased significantly at $55^{\circ} \mathrm{C}$. The low value recorded at $55^{\circ} \mathrm{C}$ may be due to the partial denaturation of enzymes at higher temperatures.

\section{Effect of different nitrogen sources for the production of alkaline enzymes}

For any organism including bacteria, a nitrogen source served as a secondary energy source for growth and enzyme secretion (Kumar et al., 2012). The effect of nitrogen sources as additives on the fermentation medium was studied. Among the different nitrogen sources used, a significant enzyme yield was observed with soybean meal and peptone for alkaline protease. However, for alkaline amylase and alkaline lipase, soybean meal, peptone and yeast extract were best nitrogen sources (Figure 6). Since the soybean meal is a cheap nitrogen source; it was chosen as the appropriate nitrogen source. The casein present in the cultivation medium served as a carbon source for alkaline protease and organic nitrogen source for all alkaline enzymes. Supportively, a combination of both soybean meal and casein was the appropriate nitrogen source for lipase production in S. rubidaea (Immanuel et al., 2008). Addition of inorganic nitrogen sources did not have a pronounced effect on all alkaline enzymes when compared to organic sources (Figure 6). Likewise, low enzyme yields were noted when inorganic nitrogen sources were used as nitrogen sources in the production of lipase and protease by $B$. pumilus SG2 (Sangeetha et al., 2008). Therefore, unlike inorganic nitrogen sources, most of the organic nitrogen sources, in addition to acting as a nitrogen source, supply vitamins, minerals and accessory growth factors in the cultivation medium that enhance bacterial growth and enzyme production (Gupta et al., 2004).

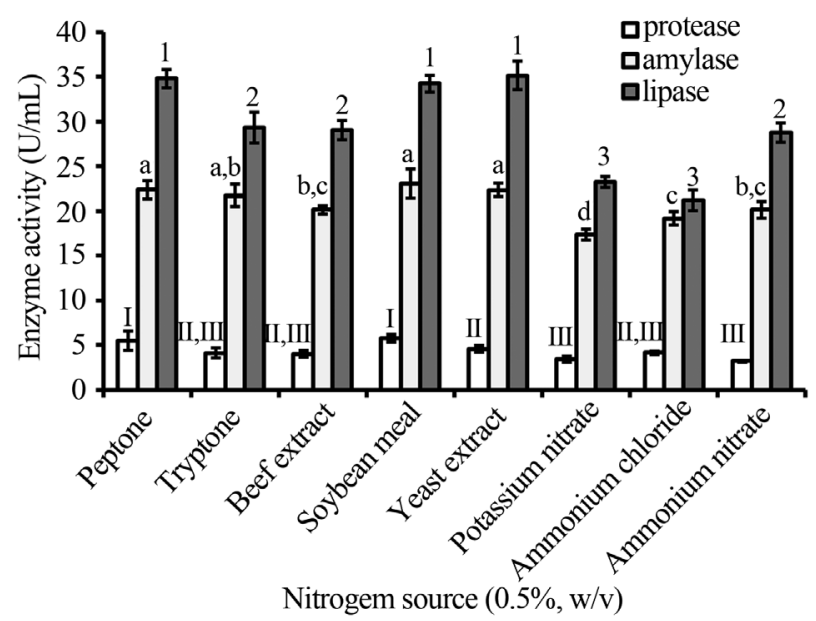

Figure 6 - Effect of nitrogen sources as supplements on enzymes production by $B$. flexus XJU-1. A medium without any nitrogen source addition was taken as the control. The significant difference at $\mathrm{P}_{0.05}$ is indicated by different letters or numerals or Roman numerals on the error bars. 


\section{Effect of varying soybean meal concentration on the production of enzymes}

A 0.5 to $3 \%$ range of soybean meal was tested in order to analyze its effect on alkaline enzyme production. A slight increase in enzyme activities was observed at $1 \%$ concentration although statistically at par with $1.5 \%$ when compared to control (data not shown). However, in the optimization of next parameter, $1 \%$ was used as it is more economical. $2 \%$ soybean meal in combination with $1 \%$ polypeptone was appropriate for the coproduction of alkaline protease and alpha amylase by $B$. subtilis IIB-26 (Mukhtar and Haq, 2012). At concentrations greater than $1.5 \%$, a decline in enzyme activities was noticed. This decrease may be probably ascribed to nitrogen metabolite repression. Ogrydziak (1993) reported same repression in the production of protease by various types of yeast.

\section{Time course study for optimal production of enzymes by Bacillus flexus XJU-1}

After optimization of nutritional and physicochemical factors, the optimized medium for all the 3 alkaline enzymes was used in order to know the optimal time for harvesting enzymes. The optimum incubation period recorded for amylase was $24 \mathrm{~h}$ while $48 \mathrm{~h}$ was registered for protease and lipase (Figure 7). Likewise, $24 \mathrm{~h}$ and $44 \mathrm{~h}$ were appropriate time for maximal amylase and protease production by Bacillus sp. Y, respectively (Shivakumar, 2012) while incubation period of $48 \mathrm{~h}$ gave higher lipase and protease yields in B. pumilus (Valasange and Bagewadi, 2012). Contrastingly, a higher incubation period of $120 \mathrm{~h}$ was recorded in the coproduction of amylase and protease by $\mathrm{Ba}$ cillus sp. HPE10 (Mukesh kumar et al., 2012b). Sangeetha et al. (2008) recorded $36 \mathrm{~h}$ (in mid log phase of growth) and $63 \mathrm{~h}$ (late log phase) as the optimal time for a protease and lipase, respectively by $B$. pumilus SG2. They concluded that the bacterium uses first a protein as carbon source and then uses a lipidic substrate after the exhaustion of the protein. When optimal incubation period was attained, further increase in incubation time led to a decrease in enzyme ac-

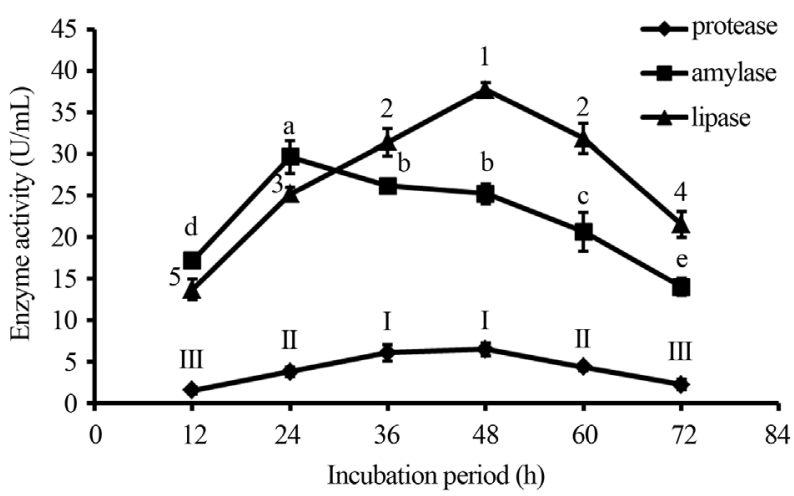

Figure 7 - Time course of alkaline enzyme production by Bacillus flexus XJU-1. The significant difference at $\mathrm{P}_{0.05}$ is indicated by different letters or numerals or Roman numerals on the error bars. tivities (Figure 7). The decrease seen after optimum incubation time has been ascribed to the shortage of some nutrients in the fermentation medium (Shivakumar, 2012). Although the decrease in lipase activity was attributed to proteolytic degradation by some authors (Maia et al., 1999; Bora and Bora, 2012), the present study showed that the produced lipase is stable in presence protease since they have same optimum incubation time of $48 \mathrm{~h}$ (Figure 7). The alkaline lipase was produced in higher amounts (37.72 $\mathrm{U} / \mathrm{mL})$ than alkaline amylase $(29.63 \mathrm{U} / \mathrm{l})$ and alkaline protease $(6.45 \mathrm{U} / \mathrm{mL})$ in this work. Similarly, in the coproduction of amylase and protease by Bacillus species, the amylase was produced in higher amounts (Mukesh kumar et al., 2012b; Shivakumar, 2012). Likewise, the lipase was produced in higher amounts than protease by B. pumilus SG2 (Sangeetha et al., 2008). However, in the concomitant production of lipase and amylase by $B$. licheniformis, the lipase yield was less than that of protease (Amara et al., 2009). This difference in enzyme production by the Bacillus species may depend on the genetic differences.

\section{Conclusion}

In the present study, alkaline $\alpha$-amylase, alkaline lipase and alkaline protease were secreted in higher amounts by $B$. flexus XJU-1 in a single cultivation under the same conditions at flask level. The production of 3 alkaline enzymes in a single cultivation medium, stability of 3 enzymes in a single mixture, the short incubation periods and use of cheap substrates (cottonseed oil and soybean meal) make the submerged fermentation cost-effective. The fermentation can be exploited at fermentor and industrial levels since the crude preparation of a mixture of these enzymes finds applications in detergent industries and other biotechnological applications. During the process, time, labor, energy and money can be saved. We are investigating further the use of crude enzyme in detergent industries.

\section{References}

Amara AA, Salem SS, Shabeb MSA (2009) The possibility to use bacterial protease and lipase as a detergent. Global J Biotechnol Biochem 4:104-114.

Anwar T, Mathur A, Mathur G, Chauhan RS (2011) Statistical optimization for coproduction and partial characterization of thermohalotolerant lipase and amylase from halotolerant Bacillus subtilis JPBW-9. World J Sci Technol 1:54-63.

Bernfield P (1955) Methods in Enzymology. Academic Press, New York.

Bora L, Bora M (2012) Optimization of extracellular thermophilic highly alkaline lipase from thermophilic Bacillus sp. isolated from hotspring of Arunachal Pradesh, India. Braz J Microbiol 43:30-42.

Gormsen E, Aaslyng D, Malmos H (1991) Mechanical studies of proteases and lipases for detergent industry. J Chem Technol Biotechnol 50:321-330. 
Gupta R, Gupta N, Rathi P (2004) Bacterial lipases: an overview of production, purification and biochemical properties. Appl Microbiol Biotechnol 64:763-781.

Hasan F, Hameed A (2001) Optimization of lipase production from Bacillus sp. Pak J Bot 33:789-796.

Hou CT, Johnston TM (1992) Screening of lipase activities with cultures from the agricultural research services culture collection. JAOCS 69:1088-1097.

Immanuel G, Esakkiraj P, Jebadhas A, Iyapparaj P, Palavesam A (2008) Investigation of lipase production by milk isolate Serratia rubidaea. Food Technol Biotechnol 46:60-65.

Kumar AP, Kumar KJ, Narasimha G (2012) Isolation of lipase producing fungi from groundnut oil mill effluent soil site at Nandyal. Int J Pharm Bio Sci 3:275-280.

Maia MD, de Morais MMC, Jr MA, Melo EHM, Filho JL (1999) Production of extracellular lipase by the phytopathogenic fungus Fusarium solani FS1. Rev Microbiol 30:304-309.

Mukesh kumar DJ, Lawrence L, Rajan R, Priyadharshini S, Sandhiyachittybabu, Kalaichelvan PT (2012a) Characterization of lipase and protease from Serratia marcescens DEPTK21 and its destaining capability. Asian J Exp Biol Sci 3:621-628.

Mukesh kumar DJ, Priyadharshini DA, Suresh K, Saranya GM, Rajendran K, Kalaichelvan PT (2012b). Production, purification and characterization of $\alpha$-amylase and alkaline protease by Bacillus sp. HPE 10 in a concomitant production medium. Asian J Plant Sci Res 2:376-382.

Mukhtar H, Haq I (2012) Concomitant production of two proteases and alpha-amylase by a novel strain of Bacillus subtilis in a microprocessor controlled bioreactor. Braz J Microbiol 43:1072-1079.

Negi S, Banerjee R (2010) Optimization of culture parameters to enhance production of amylase and protease from Aspergillus awamori in a single fermentation. Afr $\mathrm{J}$ Biochem Res 4:73-80.
Niyonzima FN, More SS (2013a) Screening and optimization of cultural parameters for an alkaline protease production by Aspergillus terreus gr. under submerged fermentation. Int $\mathrm{J}$ Pharm Bio Sci 4(1):1016-1028.

Niyonzima FN, More SS (2013b) Screening and identification of a novel alkaline lipase producing bacterium. Int J Pharm Bio Sci 4(2):1037-1045.

Ogrydziak DM (1993) Yeast extracellular proteases. Crit Rev Biotechnol 13:1-55.

Rao MB, Tanksale AM, Ghatge MS, Deshpande VS (1998) Molecular and biotechnological aspects of microbial protease. Microbiol Mol Bio Rev 62:597-635.

Sangeetha R, Geetha A, Arulpandi I (2008) Optimization of protease and lipase production by Bacillus pumilus SG 2 isolated from an industrial effluent. Internet J Microbiol 5: DOI: $10.5580 / 2126$.

Sangeetha R, Geetha A, Arulpandi I (2010) Concomitant production of protease and lipase by Bacillus licheniformsis VSG1: production, purification and characterization. Braz J Microbiol 41:179-185.

Sharma R, Chisti Y, Banerjee UC (2001) Production, purification, characterization, and applications of lipases. Biotechnol Adv 19:627-662.

Shivakumar S (2012) Co-production of alkaline protease and amylase of Bacillus sp. Y in solid state cultivations. Res J Biotech 7:32-38.

Sumathi R, Meerabai RS (2012) Lipase production by Aspergillus terreus using cottonseed oil as carbon source. Plant Arch 12:765-768.

Valasange A, Bagewadi PM (2012) Concomitant production of protease and lipase by Bacillus species isolated from compost soil. ISRJ 1:1-4.

All the content of the journal, except where otherwise noted, is licensed under a Creative Commons License CC BY-NC. 